\title{
A longitudinal cross-over study of serum cholesterol and lipoproteins in rabbits fed on semi-purified diets containing either casein or soya-bean protein
}

\author{
BY ANTHONY H. M. TERPSTRA, CHRISTOPHER J. H. WOODWARD*, \\ CLIVE E. WEST AND HENK G. VAN BOVEN \\ Department of Human Nutrition, Agricultural University, De Dreijen 12, \\ 6703 BC Wageningen, The Netherlands
}

(Received 22 January 1981-Accepted 12 October 1981)

1. Two groups, each of six rabbits, were fed on semi-purified diets containing either $400 \mathrm{~g}$ casein or $400 \mathrm{~g}$ soya-bean protein $/ \mathrm{kg}$ for $20 \mathrm{~d}$ and then the diets of the two groups were crossed-over.

2. Just before the cross-over, the serum cholesterol concentration (mean \pm SE) was $3068 \pm 592$ and $800 \pm 143 \mathrm{mg} / 1$ for the groups fed on casein and soya-bean protein respectively.

3. Changes in the serum cholesterol concentration were observed $1 \mathrm{~d}$ after crossing-over the diets. By $10 \mathrm{~d}$, the cholesterol levels in the two groups had also crossed-over.

4. The changes in serum cholesterol level after the cross-over were reffected in the very-low-density lipoproteins (VLDL) and low-density lipoproteins (LDL).

5. Lipoprotein protein concentrations in the LDL changed in the same way as cholesterol. In the VLDL however, the protein concentration decreased in both groups after the change in diet.

6. The cholesterol: protein values for the LDL and VLDL markedly increased in the rabbits changed from the soya-bean-protein diet to the casein diet, reaching a maximum $2 \mathrm{~d}$ after the cross-over. In the animals switched from casein to soya-bean protein, the values progressively declined.

7. The source of dietary protein exerts a rapid effect on the composition of both the VLDL and LDL which is proposed to be attributed to changes in the number and size of lipoprotein particles.

Over 70 years ago, it was observed that rabbits fed on a diet rich in animal products developed atherosclerotic lesions, and it was suggested that the protein might be the component responsible (Ignatowski, 1909). However, this idea was largely abandoned when Anitschkow \& Chalatow (1913) found that the inclusion of cholesterol in the diet resulted in similar lesions. Nevertheless, several investigators still adhered to the idea that dietary protein might play an important role in the aetiology of hypercholesterolaemia and atherosclerosis. Newburgh \& Squier (1920) observed that feeding high-casein diets to rabbits produced atherosclerosis, whereas the feeding of soya-beans did not. Similar results were later reported by Meeker and Kesten (1941). More recently it has been clearly shown that cholesterol metabolism in rabbits can be influenced by dietary protein (Carroll \& Hamilton, 1975; Hermus, 1975; Kritchevsky, 1979). Rabbits fed on semi-purified diets containing casein exhibit hypercholesterolaemia and atherosclerosis whereas substituting soya-bean protein for casein in such diets results in these effects being much reduced.

The excess of serum cholesterol in rabbits fed on a diet containing casein has been found to be carried mainly in the low-density lipoproteins (LDL) and the very-low-density lipoproteins (VLDL) (Brattsand, 1976; Ross et al. 1978; Roberts et al. 1979; Lacombe \& Nibbelink, 1980; Terpstra \& Sanchez-Muniz, 1981; Terpstra, Harkes et al. 1981). With moderate hypercholesterolaemia, the LDL fraction is the main carrier of serum cholesterol, whereas at more elevated levels of serum cholesterol most of the cholesterol is transported in the VLDL particles (Terpstra, Harkes et al. 1981).

* Present address: Department of Biochemistry, University of Western Ontario, Health Sciences Center. London N6A 5Cl, Ontario, Canada. 
Lipoprotein protein and phospholipid concentrations also change when rabbits are switched from commercial diets to semi-purified diets containing either casein or soya-bean protein (Roberts et al. 1979; Terpstra \& Sanchez-Muniz, 1981). However, the different lipoprotein components do not change proportionately, so that the composition of lipoproteins from rabbits fed on casein differs from that of animals fed on soya-bean protein; the cholesterol:protein value is greater in animals fed on casein diets.

In a previous study (Terpstra \& Sanchez-Muniz, 1981) the time-course of alterations in serum lipids and lipoprotein composition was examined when rabbits were switched from a commercial diet to semi-purified diets containing either casein or soya-bean protein. It was found that significant changes occurred after only $1 \mathrm{~d}$ of feeding the semi-purified diets. In the present experiment, the time-course of changes in serum lipoproteins has been studied after switching rabbits from a semi-purified diet containing casein to a semi-purified diet containing soya-bean protein and vice versa. High-protein diets have been used to enhance the differences between the groups; by raising the proportion of dietary protein, hypercholesterolaemia due to casein is enhanced, whereas changes in the proportion of soya-bean protein in the diet do not affect serum cholesterol levels (Huff et al. 1977; Terpstra, Harkes et al. 1981).

\section{METHODS}

\section{Animals and experimental design}

In the experiment, two groups each of six male New Zealand White rabbits, aged 13 weeks, were used. The animals were housed individually in cages with wire-mesh bases constructed of galvanized steel and were kept in a room with air-conditioning and a $12 \mathrm{~h}$ light-dark cycle. The rabbits had been fed on commercial rabbit pellets (Trouw en Co N.V. 3881 LB Putten, The Netherlands) and were subsequently transferred, without an adaption period, to pelleted semi-purified diets containing either $400 \mathrm{~g}$ casein or $400 \mathrm{~g}$ soya-bean protein $/ \mathrm{kg}$. The composition of the diets was $(\mathrm{g} / \mathrm{kg})$ : maize starch 180 , dextrose 122 , coconut oil 40 , soya-bean oil 10 , sawdust 12 , casein or soya-bean protein 400 , vitamin premix 12 , mineral premix 10, $\mathrm{KHCO}_{3} 18, \mathrm{CaHPO}_{4} .2 \mathrm{H}_{2} \mathrm{O} 29, \mathrm{NaCl} 4, \mathrm{MgO} 2, \mathrm{MgCO}_{3} 3$, molasses 50. The compositions of the vitamin and mineral premixes have been described earlier (Hermus, 1975). After feeding the semi-purified diets for $20 \mathrm{~d}$, the group receiving the casein diet was changed to the diet containing soya-bean protein, whereas the animals fed on the soya-bean-protein diet were switched to the casein diet. After the cross-over the rabbits were kept on the diets for a further $35 \mathrm{~d}$.

Food and water were provided $a d$ lib. The individual food consumption was measured daily and body-weight weekly. Blood samples from non-fasted animals were taken by incision from the marginal ear vein between 08.00 and 10.00 hours. The days on which blood samples were collected for the estimation of total serum cholesterol $(O)$ and the separation of serum lipoproteins $(\mathcal{O})$ are as follows:

$$
\text { First period (20d) Second period (35 d) }
$$

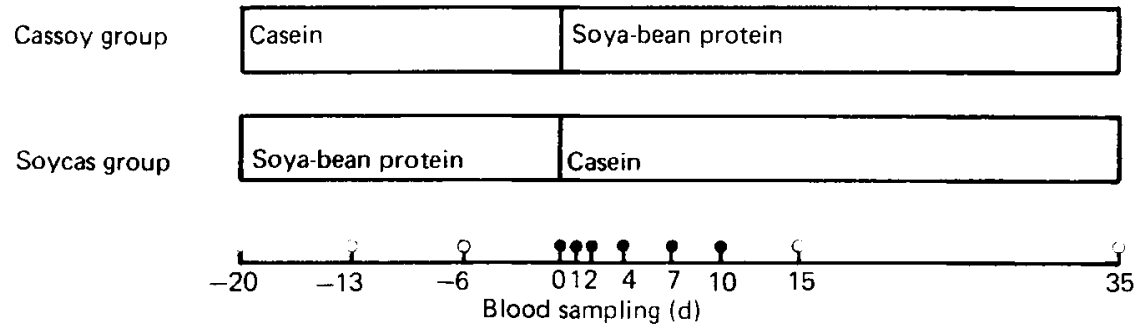


Table 1. Body-weight, weight gain and food intake of rabbits fed on semi-purified diets containing either casein or soya-bean protein*

(Mean values with their standard errors for six rabbits/dietary group)

\begin{tabular}{|c|c|c|c|c|}
\hline & \multicolumn{2}{|c|}{ Cassoy group $\dagger$} & \multicolumn{2}{|c|}{ Soycas group +} \\
\hline & Mean & $\mathrm{SE}$ & Mean & $\mathrm{SE}$ \\
\hline \multicolumn{5}{|l|}{ Body-wt (g): } \\
\hline Initial (on day -20 ) & 1667 & 96 & 1859 & 69 \\
\hline On day 0 & 2163 & 84 & 2556 & 89 \\
\hline Final (on day 35) & 3073 & 131 & 3268 & 118 \\
\hline \multicolumn{5}{|l|}{ Wt gain $(\mathrm{g} / \mathrm{d})$ during: } \\
\hline First period & 23-7 & $2 \cdot 3$ & $31 \cdot 8$ & $5 \cdot 2$ \\
\hline Second period & $26 \cdot 0$ & $4 \cdot 1$ & $21 \cdot 8$ & 2.4 \\
\hline Whole experiment & $25 \cdot 1$ & 2.6 & $25 \cdot 2$ & 2.6 \\
\hline \multicolumn{5}{|l|}{ Food intake $(\mathrm{g} / \mathrm{d})$ during: } \\
\hline First period & $82 \cdot 7$ & 5.9 & $112 \cdot 7$ & $8 \cdot 7$ \\
\hline Second period & $116 \cdot 6$ & $9 \cdot 3$ & $106 \cdot 0$ & $5 \cdot 2$ \\
\hline
\end{tabular}

* Individual food intake was measured daily and body-weight weekly.

$\dagger$ The cassoy group was fed on the casein diet during the first period of $20 \mathrm{~d}$ and then after the cross-over the soya-bean protein diet during the second period of $35 \mathrm{~d}$.

$\ddagger$ The soycas group was fed on the soya-bean protein diet during the first period of $20 \mathrm{~d}$ and then after the cross-over the casein diet during the second period of $35 \mathrm{~d}$

\section{Analytical methods}

The serum lipoproteins were separated by density gradient ultracentrifugation, employing a slight modification of the method described previously (Terpstra, Woodward et al. 1981). In a polyallomer centrifuge tube (Beckman Inc., Palo Alto CA 94304) designed to fit the Beckman SW 50.1 rotor was placed $1 \mathrm{ml}$ serum. The serum lipoproteins were prestained by mixing the serum carefully with $0.1 \mathrm{ml}$ Sudan Black solution prepared as described by Narayan (1975). The background density of the prestained serum was raised to $1 \cdot 10 \mathrm{~g} / \mathrm{ml}$ by adding $114 \mathrm{mg} \mathrm{KBr}$ and $25 \mathrm{mg}$ sucrose. Subsequently, the mixture was overlayered with equal volumes $(2.1 \mathrm{ml})$ of a salt solution of density $1.05 \mathrm{~g} / \mathrm{ml}(11.42 \mathrm{~g} \mathrm{NaCl}$ and $61.65 \mathrm{~g} \mathrm{KBr} / 1$ ) and distilled water. The samples were spun for $16 \mathrm{~h}$ in an SW 50.1 rotor at $20^{\circ}$ and $50000 \mathrm{rev} / \mathrm{min}(234000 \mathrm{~g})$, using a Beckman L5-65 ultracentrifuge. After centrifugation, three stained bands were visible in the density gradient; on top of the gradient the VLDL fraction, further down in the tube the LDL particles and on the bottom the high-density lipoproteins (HDL) together with the serum proteins. The three lipoprotein fractions were collected by tube slicing on the basis of their visible positions in the gradient and analysed for cholesterol and protein. Cholesterol in whole serum and the lipoprotein fractions was measured by the method of Röschlau et al. (1974), using the catalase kit supplied by Boehringer Mannheim, Germany. The protein in the VLDL and LDL was estimated by the method of Lowry et al. (1951) as modified by Markwell et al. (1978).

Statistical analysis was performed using the two-tailed Wilcoxon test (Snedecor \& Cochran, 1967).

\section{RESULTS}

Food consumption and growth

The body-weight, weight gain and food consumption of the two groups of rabbits are presented in Table 1. Both diets were well accepted throughout the experiment and supported adequate growth rates. However, the food intake tended to be higher, when the 


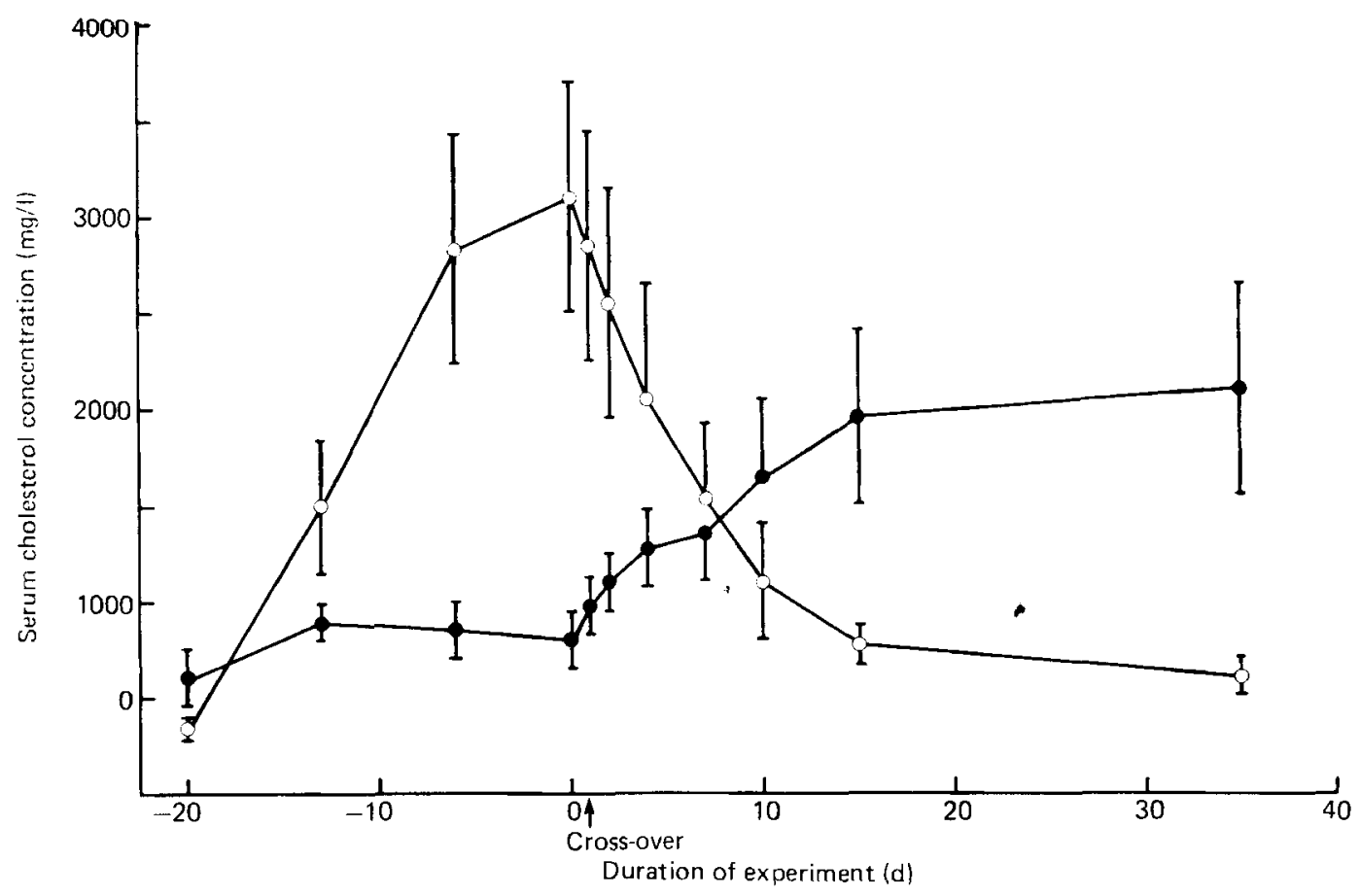

Fig. 1. Serum cholesterol concentration in rabbits fed on semi-purified diets containing either casein or soya-bean protein. ( $\mathrm{O}-\mathrm{O}$ ), Group receiving diet containing casein before the cross-over and soya-bean protein after the cross-over (cassoy group); $(-0)$, soya-bean protein and casein, respectively (soycas group). Points are values for six rabbits with their standard errors represented by vertical bars.

rabbits were fed on the semi-purified diet containing soya-bean protein than that containing casein. These differences in food intake paralleled the growth rates. Nevertheless, throughout the whole experiment both groups had achieved a similar weight gain.

\section{Serum cholesterol}

The semi-purified casein diet resulted in markedly elevated levels of serum cholesterol whereas the soya-bean diet maintained the serum cholesterol concentration low (Fig. 1). At the end of the first period this difference was highly significant $(P<0.01)$. When the rabbits on the casein diet were transferred to the diet containing soya-bean protein (cassoy group), a rapid decrease in serum cholesterol occurred. After only $1 \mathrm{~d}$ a decrease in serum cholesterol of $245 \mathrm{mg} / 1$ was observed. Conversely, changing the rabbits from the diet containing soya-bean protein to the casein diet (soycas group) resulted in an increase in serum cholesterol of $167 \mathrm{mg} / \mathrm{I}$ after only I d. These changes continued; the serum cholesterol level in the cassoy group progressively decreasing and that in the soycas group increasing. By $10 \mathrm{~d}$ after the change-over, the cholesterol levels in the two groups had crossed-over. By the end of the whole experiment, the concentration in the cassoy group had returned essentially to its initial value. At the same time, the cholesterol concentration in the soycas group had increased to $2100 \mathrm{mg} / \mathrm{l}$ which is rather less than the maximum for the cassoy group. 
Table 2. Concentration of cholesterol and protein $(\mathrm{mg} / \mathrm{l})$ in serum lipoprotein fractions of rabbits fed on semi-purified diets containing either casein or soya-bean protein $\dagger$

(Mean values with their standard errors for six rabbits/dietary group)

\begin{tabular}{|c|c|c|c|c|c|c|c|c|c|c|c|c|c|}
\hline \multicolumn{2}{|c|}{ Day of experiment... } & \multicolumn{2}{|c|}{0} & \multicolumn{2}{|c|}{1} & \multicolumn{2}{|c|}{2} & \multicolumn{2}{|c|}{4} & \multicolumn{2}{|c|}{7} & \multicolumn{2}{|c|}{10} \\
\hline & & Mean & $\mathrm{SE}$ & Mean & $\mathrm{SE}$ & Mean & SE & Mean & $\mathrm{SE}$ & Mean & SE & Mean & $\mathrm{SE}$ \\
\hline Group & Cholesterol & & & & & & & & & & & & \\
\hline \multirow[t]{3}{*}{ Cassoy } & VLDL & 941 & $242 * *$ & 779 & $321^{*}$ & 450 & $160^{*}$ & 349 & 220 & 227 & 49 & 181 & 49 \\
\hline & LDL & 1669 & $449^{* *}$ & 1669 & $441^{* *}$ & 1540 & $414^{*}$ & 1258 & 408 & 927 & 406 & 623 & 247 \\
\hline & HDL & 258 & 42 & 349 & 39 & 386 & 24 & 480 & 61 & 394 & 51 & 285 & 50 \\
\hline \multirow[t]{4}{*}{ Soycas } & VLDL & 107 & 21 & 111 & 10 & 120 & 21 & 183 & 27 & 185 & 45 & 212 & 50 \\
\hline & LDL & 271 & 89 & 456 & 98 & 518 & 101 & 655 & 151 & 702 & 228 & 865 & 301 \\
\hline & $\mathrm{HDL}$ & 365 & 73 & 396 & 78 & 455 & 73 & 459 & 61 & 512 & 90 & 521 & 102 \\
\hline & Protein & & & & & & & & & & & & \\
\hline \multirow[t]{2}{*}{ Cassoy } & VLDL & 282 & 74 & 226 & 76 & 133 & $42^{*}$ & 123 & 68 & 144 & 38 & 112 & 14 \\
\hline & LDL & 859 & $172^{* *}$ & 843 & $163^{* * *}$ & 825 & $190^{*}$ & 650 & 174 & 611 & 135 & 444 & 113 \\
\hline \multirow[t]{2}{*}{ Soycas } & VLDL & 227 & 160 & 281 & 223 & 46 & 10 & 101 & 24 & 81 & 16 & 93 & 16 \\
\hline & LDL & 296 & 30 & 329 & 55 & 309 & 54 & 429 & 78 & 414 & 94 & 484 & 129 \\
\hline
\end{tabular}

† VLDL, very-low-density lipoproteins; LDL, low-density lipoproteins, HDL, high-density lipoproteins. The cassoy and soycas group were fed on semi-purified diets containing casein and soya-bean protein for a period of $20 \mathrm{~d}$ and were changed on day 0 to a soya-bean and casein diet respectively.

The difference was statistically significant between values for the cassoy and soycas group: ${ }^{*} P<0 \cdot 05$, ** $P<0.01$.

\section{Lipoprotein composition}

The cholesterol and protein levels in the different lipoprotein fractions are shown in Table 2. Immediately before the dietary cross-over, the cassoy group exhibited significantly higher concentrations of cholesterol in the VLDL and LDL fractions when compared to the soycas group. After the cross-over, the cassoy group showed a progressive decrease in both VLDL and LDL cholesterol. However, initially only a decrease in VLDL cholesterol was observed, followed by a subsequent decrease of the cholesterol concentration in the LDL fraction. On the other hand, in the soycas group the progressive elevation in serum cholesterol was mainly reflected by increased LDL cholesterol, whereas the contribution of the VLDL was relatively small. HDL cholesterol showed in both groups an increasing tendency, but declined in the cassoy group on day 10 after the cross-over.

The LDL protein concentration in the cassoy group showed a progressive decline, whereas that in the soycas group increased. However, VLDL protein decreased in both groups. The first changes in protein concentration of both groups occurred in VLDL and were clearly established $2 \mathrm{~d}$ after the cross-over. Changes in LDL protein did not become obvious for $4 \mathrm{~d}$.

In Fig. 2 and Fig. 3, the values cholesterol:protein in VLDL and LDL are presented. These provide an indication of the composition of the lipoprotein particles, and they reflect the concurrent alterations in cholesterol and protein levels which have been described previously. Immediately before the dietary change-over, these values were significantly higher in the cassoy group than in the soycas group $(P<0.05)$. After the cross-over, the cholesterol:protein value in the VLDL of the cassoy group showed a progressive decrease, which first appeared on day 4 after the cross-over. In the soycas group this value increased markedly on the second day and thereafter remained at a higher level. In the LDL the pattern is similar; the value in the cassoy group began to decrease on the first day and this trend continued up to day 10 . In the soycas group the initial increase on the first day continued up to the second day, at which level the cholesterol:protein value was constant. 


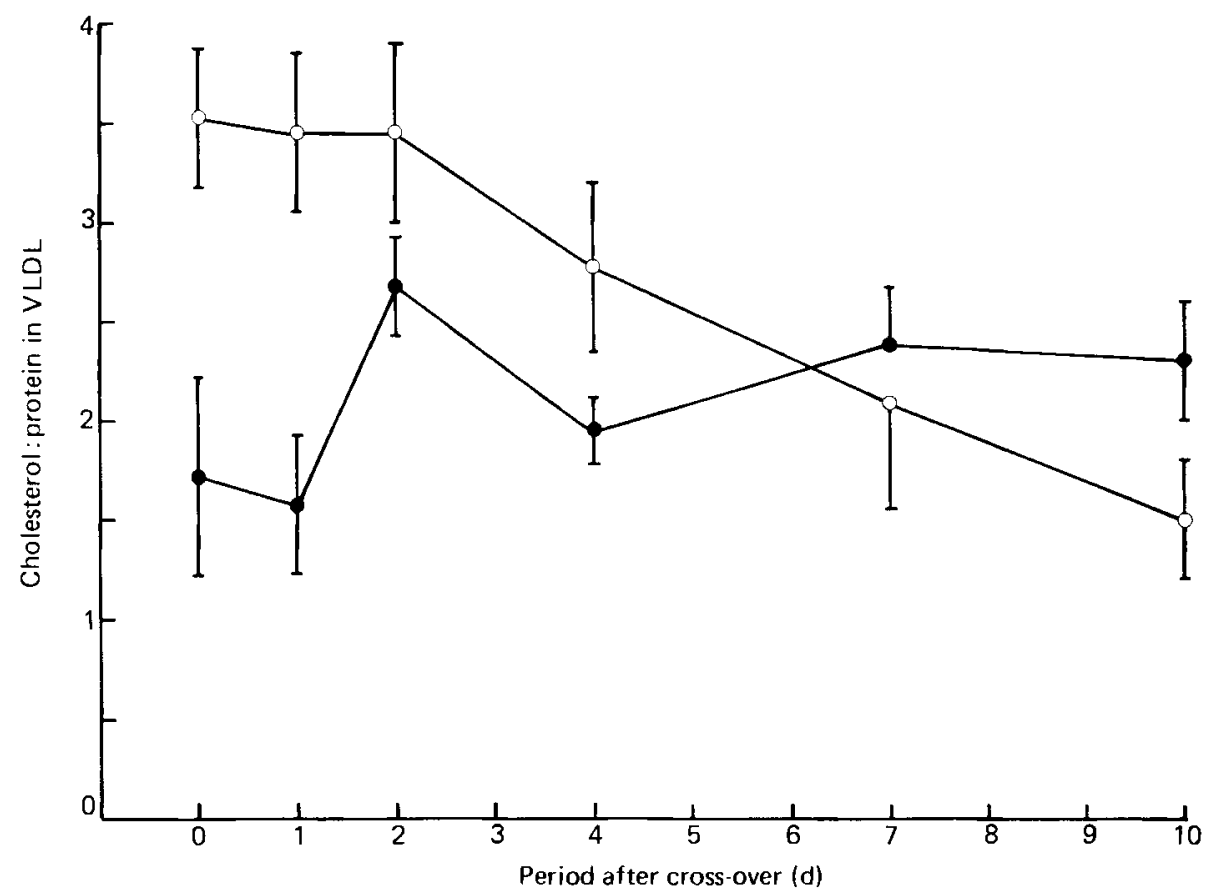

Fig. 2. Cholesterol:protein in very-low-density lipoproteins (VLDL) after the cross-over in rabbits fed on semi-purified diets containing either casein or soya-bean protein. $(\mathrm{O}-\mathrm{O})$, Group changed from the casein diet to the soya-bean protein diet (cassoy group); ( $-O$ ), group changed from the soya-bean protein diet to the casein diet (soycas group). Points are mean values for six rabbits with their standard errors represented by vertical bars.

\section{DISCUSSION}

In a previous study (Terpstra \& Sanchez-Muniz, 1981) the time-course of the changes in lipoprotein composition were studied in rabbits switched from a commercial diet to semi-purified diets containing either casein or soya-bean protein. The aim of the present study was to examine the development and regression of hypercholesterolaemia when rabbits were changed from a semi-purified diet containing soya-bean protein to a semi-purified diet containing casein and vice versa. In order to enhance the effects, high-protein diets were used.

When the soycas group was switched to the casein diet, an increase in serum cholesterol of $167 \mathrm{mg} / \mathrm{l}$ occurred after only $1 \mathrm{~d}$. After $2 \mathrm{~d}$ marked elevations in cholesterol:protein of the VLDL and LDL were observed. However, in the previous study (Terpstra \& Sanchez-Muniz, 1981), when rabbits were switched from a commercial diet to a semi-purified diet these changes were even more pronounced and rapid, despite a lower proportion of casein in the diet $(200 \mathrm{~g} / \mathrm{kg})$. After $1 \mathrm{~d}$ the serum cholesterol levels rose by $510 \mathrm{mg} / \mathrm{l}$ and cholesterol:protein in VLDL and LDL more than doubled over the same time. There may be several explanations for these differences. First, in the present study, only the protein source in the diet was changed, whereas in the previous experiment the diet as a whole was different. It has been shown that in rabbits, dietary components other than protein also play an important role in determining serum cholesterol levels (Hamilton \& Carroll, 1976; Kritchevsky et al. 1977). Secondly, there might be an age-effect. Ignatowski (1909) previously noticed that young rabbits were more susceptible to atherosclerosis produced by dietary means than their older counterparts. Furthermore, experiments in our laboratory have clearly shown, that the effect of dietary protein on serum 


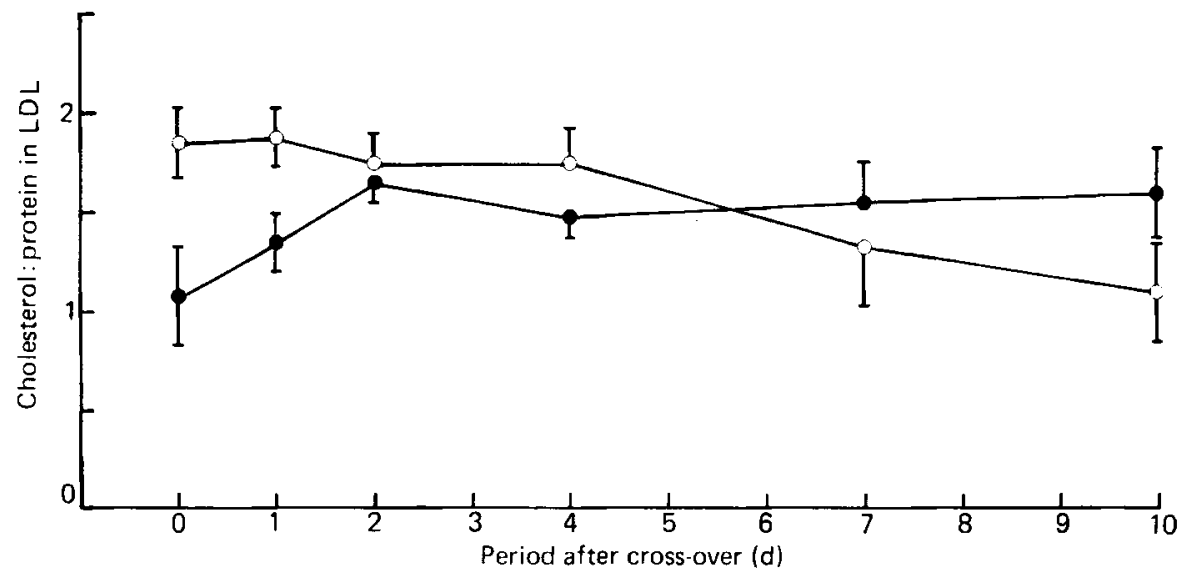

Fig. 3. Cholesterol:protein in low-density lipoproteins (LDL) in rabbits fed on semi-purified diets containing either casein or soya-bean protein. $(\mathrm{O}-\mathrm{O})$, Group changed from the casein diet to the soya-bean protein diet (cassoy group); (C-C), Group changed from the soya-bean protein diet to the casein diet (soycas group). Points are mean values for six rabbits with their standard errors represented by vertical bars.

cholesterol is markedly reduced in adult rabbits (West \& Terpstra, unpublished results). When the animals in the present study were transferred to another semi-purified diet, their age was 16 weeks, whereas the rabbits in the previous experiment were 13 weeks during the change-over. This age-effect might also explain why the soycas group on the casein diet did not reach such a high serum cholesterol level as the cassoy group when fed on casein, although the casein diet was fed for a much longer period. Finally, it should be noticed that the serum cholesterol levels of the soycas group were higher before the cross-over than in the animals in the previous experiment when changed from a commercial diet to a semi-purified casein diet $(400 v: 800 \mathrm{mg} / \mathrm{l})$. This might also have affected the results.

The cassoy group exhibited immediately before the dietary change-over significantly higher levels of VLDL- and LDL-cholesterol compared to the soycas group. Ten $d$ after the cross-over, most of the increase in serum cholesterol of the soycas group was transported in the LDL fraction whereas the VLDL cholesterol had only slightly increased. This different pattern might be explained by the differences in total serum cholesterol in the cassoy group just before the cross-over $(3086 \pm 592 \mathrm{mg} / \mathrm{l})$ and the soycas group $10 \mathrm{~d}$ afterwards $(1647 \pm 410 \mathrm{mg} / \mathrm{l})$. It has been observed previously (Terpstra, Harkes et al. 1981) that at moderate elevated levels of serum cholesterol most of the cholesterol is transported by the LDL while at markedly increased serum cholesterol concentrations the VLDL fraction becomes a major carrier of cholesterol.

The protein concentrations in the LDL fraction of both the cassoy and soycas groups changed in the same way as cholesterol in these particles. On the other hand, VLDL protein declined in both groups. However, it is possible that this decrease of VLDL protein in the soycas group is only transient. As pointed out previously, $10 \mathrm{~d}$ after the cross-over the total serum cholesterol in the soycas group had only moderately increased and only minor elevations in VLDL cholesterol had occurred. Nevertheless, $2 \mathrm{~d}$ after the cross-over, cholesterol:protein in the VLDL fraction had markedly increased due to a decrease in VLDL-protein concentration. A similar pattern of response was observed when rabbits were changed from a commercial diet to a semi-purified casein diet (Terpstra \& Sanchez-Muniz, 1981). It seems likely that the concentration of VLDL protein will increase later, when there is an accumulation of cholesterol in the VLDL.

At $10 \mathrm{~d}$ after the cross-over a similar concentration of VLDL cholesterol was measured 
in the soycas and cassoy group. Nevertheless, cholesterol:protein was higher in the soycas group. This might indicate that in rabbits fed on casein, VLDL particles are synthesized with a different composition than in rabbits fed on soya-bean protein. Since VLDL particles are assumed to be metabolized into LDL particles (Eisenberg, 1979), this might also result in LDL particles with a high cholesterol:protein value. It is noteworthy, that in the cassoy group, the decrease in cholesterol:protein of the LDL was preceded by a decline of this value in the VLDL. This might also be explained by a subsequent conversion of VLDL into LDL particles. However, it should be taken into account that blood samples were taken in non-fasted state and that the VLDL fraction also contains chylomicrons. Therefore, changes reported in the VLDL composition possibly reflect, to some extent, changes in the composition of chylomicrons.

On switching rabbits from a commercial diet to semi-purified diets, cholesterol:protein in the lipoprotein fractions increased markedly on the first day and later relatively minor alterations in this value were observed (Terpstra \& Sanchez-Muniz, 1981). This was interpreted as showing that semi-purified diets produce a rapid change in lipoprotein composition, which is possibly followed by an increase of the number of lipoprotein particles. In the present experiment, a similar pattern was apparent for rabbits changed from a diet containing soya-bean protein to one containing casein, and a similar explanation may therefore be invoked. During the regression of hypercholesterolaemia in the cassoy group, the pattern is however, somewhat different. The cholesterol and protein levels fall more in parallel, suggesting simultaneous changes in composition and number.

The results of this study clearly show that soya-bean protein is able to reduce hypercholesterolaemia. Similar findings have been reported by Sirtori et al. (1979) in hypercholesterolaemic patients, when soya-bean-protein diets were consumed. Sirtori $e t$ al. (1979) reported that in type IIB-III patients, who have elevated LDL- and VLDLcholesterol, a reduction of cholesterol in both the LDL and VLDL fraction occurred. On the other hand in type IIA and IIB patients, characterized by elevated LDL levels, the reduction in serum cholesterol was mainly reflected in the LDL. Similar findings were observed in the present study with rabbits. The cassoy group exhibited just before the cross-over elevated levels of both LDL- and VLDL-cholesterol. On feeding soya-bean protein initially a decrease in VLDL-cholesterol occurred followed by a subsequent decrease in LDL. When the cholesterol in the VLDL had reached a rather low level $(7 \mathrm{~d}$ after the cross-over), a further decrease in serum cholesterol was mainly reflected in the LDL.

In conclusion, the present study has clearly shown a differential effect of dietary casein and soya-bean protein on the serum cholesterol levels and lipoprotein composition. Further, the time of regression and progression of hypercholesterolaemia induced by semi-purified diets containing soya-bean protein and casein, respectively, has been studied. This information might provide a basis for further studies on the mechanism underlying the cholesterolaemic effects of various dietary proteins.

The authors are most grateful to the staff of the Institute for Animal Nutrition Research (ILOB-TNO) 6709 PJ Wageningen, The Netherlands, for help in carrying out this experiment; Ing J. B. Schutte and Mr K. Deuring for taking care of the rabbits and $\mathrm{Mr}$ $\mathrm{P}$. Roeleveld and $\mathrm{Mr} \mathrm{M}$. Bouius for preparing the semi-purified diets.

\section{REFEREN CES}

Anitschkow, N. \& Chalatow, S. (1913). Centralbl. allgem. Path. path. Anat. $24,1$.

Brattsand, R. (1976). Atherosclerosis 23, 97

Carroll, K. K. \& Hamilton. R. M. G. (1975). J. Fd Sci. 40, 18.

Eisenberg, S. (1979). In Lipoprotein Metabolism, p. 139 [S. Eisenberg, editor]. Basal, New York : S. Karger.

Hamilton, R. M. G. \& Carroll, K. K. (1976). Atherosclerosis 24, 47. 
Hermus, R. J. J. (1975). Experimental Atherosclerosis in Rabbits on Diets with Milk Fat and Different Proteins. Wageningen, The Netherlands: Centre for Agricultural Publishing and Documentation.

Huff, M. W., Hamilton, R. M. G. \& Carroll, K. K. (1977). Atherosclerosis 28, 187.

Ignatowski, A. (1909). Virchows Arch. path. Anat. Physiol. klin. Med. 198, 248.

Kritchevsky, D. (1979). J. Am. Oil Chem. Soc. 56, 135.

Kritchevsky, D., Tepper, S. A., Williams, D. E. \& Story, J. A. (1977). Atherosclerosis $26,397$.

Lacombe, C. \& Nibbelink, M. (1980). Artery 6, 280.

Lowry, O. H., Rosebrough, N. J., Farr, A. L. \& Randall, R. J. (1951). J. biol. Chem. 193, 265.

Markwell, M. A. K., Haas, S. M., Bieber, L. L. \& Tolbert, N. E. (1978), Analyt. Biochem. 87, 206.

Meeker, D. R. \& Kesten, H. D. (1941). Arch. Path. 31, 147.

Narayan, K. A. (1975). In Analysis of Lipids and Lipoproteins, p. 225 [E. G. Perkins, editor]. Champaign, Ill.: American Oil Chemists Society.

Newburgh, L. H. \& Squier, T. L. (1920). Archs intern. Med. 26, 38.

Roberts, D. C. K., Huff, M. W. \& Carroll, K. K. (1979). Lipids 14, 566.

Röschlau, P., Bernt, E. \& Gruber, W. (1974). Z. klin. Chem. klin. Biochem. 12, 403.

Ross, A. C., Minick, C. R. \& Zilversmit, D. B. (1978). Atherosclerosis 29, 301.

Sirtori, C. R., Gatti, E., Montero, O., Conti, F., Agradi, E., Tremoli, E., Sirtori, M., Fraterrigo, L., Tavazzi, L. \& Kritchevsky, D. (1979). Am. J. clin. Nutr. 32, 1645.

Snedecor, G. W. \& Cochran, W. G. (1967). Statistical Methods, 6th ed. p. 130. Ames Iowa: State University Press. Terpstra, A. H. M., Harkes, L. \& van der Veen, F. H. (1981). Lipids 16, 114.

Terpstra, A. H. M. \& Sanchez-Muniz, F. J. (1981). Atherosclerosis 39, 217.

Terpstra, A. H. M., Woodward, C. J. H. \& Sanchez-Muniz, F. J. (1981). Analyt. Biochem. 111, 149. 